\title{
A Public Role for the Intentional Torts
}

Dan Priel

Osgoode Hall Law School of York University, dpriel@osgoode.yorku.ca

\section{Source Publication:}

King's Law Journal. Volume 22, Number 2 (2011) ,p. 183-208.

Follow this and additional works at: https://digitalcommons.osgoode.yorku.ca/scholarly_works (c) (1) ()

This work is licensed under a Creative Commons Attribution-Noncommercial-No Derivative Works 4.0 License.

\section{Recommended Citation}

Priel, Dan. "A Public Role for the Intentional Torts." King's Law Journal 22.2 (2011) ,p. 183-208.

This Article is brought to you for free and open access by the Faculty Scholarship at Osgoode Digital Commons. It has been accepted for inclusion in Articles \& Book Chapters by an authorized administrator of Osgoode Digital Commons. 


\section{A Public Role for the Intentional Torts}

\section{Dan Priel*}

\section{INTRODUCTION}

Recent years have seen wide-ranging debates on the nature of tort law. For some, tort law is firmly placed within private law: it is concerned with the rights individuals have against each other and with the legal implications of the violation of those rights. Others emphasise the extent to which broad social considerations enter into the determination of tort liability and the many ways in which tort law today serves a public role that is illexplained by the private law model. Given the centrality of negligence in contemporary tort law, much of this debate focused on this tort, but recent litigation that culminated in the House of Lords' decision in Ashley $v$ Chief Constable of Sussex Police ${ }^{1}$ and some academic commentary relating to it provide an opportunity for examining these questions in the context of the intentional torts.

Though it will be some time before I get to discuss Ashley, it will be useful to describe its facts right away. The police had gathered information that James Ashley was involved in illegal activities including drug dealing. They obtained a warrant to search his house and decided to raid it in the middle of the night. When a police unit entered the house, Ashley got up from his bed and walked towards the police officers with his hands pointing towards them as though holding a gun. One of the police officers, PC Sherwood, fired a single shot 
that hit Ashley in the neck. Ashley was severely wounded, and despite the police officers' attempts at resuscitation and the prompt arrival of an ambulance, in less than an hour Ashley was pronounced dead. Ashley' s dependants sued the police for negligence and trespass to the person with regard to the actions that led to his death, as well as for misfeasance in public office with regard to certain events that took place after the shooting. As the police admitted negligence they argued that there would be no point in a trial on the trespass claim. The trial court accepted the argument, but the Court of Appeal (Auld LJ dissenting) reversed and the House of Lords, against the dissenting opinions of Lords Carswell and Neuberger, upheld the Court of Appeal' s decision.

This outcome, coupled with the fact that some of the judges invoked the notion of 'vindication of rights' , a shibboleth for proponents of the private conception of tort law, has led most commentary on the case to consider it an affirmation of this view of tort law. ${ }^{2}$ One purpose of this essay is to show that this is, at best, an incomplete account of the judges' views expressed in the case. My real concern, however, is broader. With the aid of this case I seek to challenge the private law conception of tort liability exactly in the context of those torts usually thought to be the best affirmation of this conception of tort law. ${ }^{3}$

My discussion therefore begins far from the intentional torts. I consider some of the important developments that have changed the face of negligence liability in the last few decades and argue that, though very different, they all have in common the introduction into the decision on tort liability of considerations that look beyond the litigants. The next question is whether a similar trend can be identified with regard to the intentional torts. I argue that we can identify a role for the intentional torts within a tort regime dominated by the tort of negligence, a role that has much more to do with broad societal (or public) considerations than with those confined to the individual parties involved. More 
concretely, in sections II and III I distinguish between three possible interpretations of vindication of rights, two consistent with the private law view of tort law and the third one that is not. I argue that the two private law interpretations of vindication are unsuccessful, but that the third one provides a limited but potentially useful role for the intentional torts. As it happens, it is this, more public conception of vindication that was explicitly adopted by some of the judges in Ashley, and which, I contend, provides the best justification for the decision.

\section{HOW TORT LAW BECAME PUBLIC}

Given the age and centrality of tort law, one would be forgiven for thinking that its basic principles should be settled by now; but as many have noticed and some have lamented it is constantly changing. At first blush it seems that changes have mostly been in the direction of limiting liability, with the House of Lords using everything at its disposal to achieve this goal: distinguishing new cases from earlier ones on flimsy grounds, ${ }^{4}$ making unsubstantiated claims about the effects of expanding liability, ${ }^{5}$ limiting past decisions by declaring them 'acceptable on [their] own facts' ${ }^{6}$ narrowly interpreting the elements of existing torts, ${ }^{7}$ and rewriting past decisions so as to effectively overrule them without saying so. ${ }^{8}$ When all else has failed, the judges have not shied away from explicitly overruling an earlier decision in order to limit the scope of tort liability. ${ }^{9}$

These changes, significant though they are, appear from a broader perspective to be a rearguard battle against an ever-expanding tort law. There are various reasons for this, of which only a small number can be addressed here. One reason for the changes has to do 
with the substantial increase in the prevalence of accidents after the industrial revolution. That tort law now primarily deals with accidents not only explains why negligence is much more important than it used to be; it also changed the foundations of tort law. Two main features are worth highlighting: first, with industrialisation it became commonplace that momentary inadvertence could lead to serious accidents, which made it difficult to associate tort liability with moral fault; relatedly, industrialisation also weakened the connection between the degree of fault and the amount of harm caused (and hence damages award). Although the language of 'fault' has been retained, these developments meant that tort liability (especially in negligence) no longer corresponded well to perceptions of moral fault. Ideas such as loss spreading and general deterrence began to appear in both academic work and judicial opinions in its place, and these have led to the introduction of broader social considerations into the decision whether tort liability should be imposed or not. From this it was but a small step to the view that tort law could serve as a regulatory device and to the extent necessary should be refashioned accordingly

The untying of fault from liability and the emergence of new bases for the imposition of tort liability also affected the legitimacy of insurance in the context of tort liability. In the nineteenth century, liability (third party) insurance was still considered morally and legally suspect due to its potential to relieve defendants of their legal liabilities, and by

implication their moral responsibilities. ${ }^{10}$ Once the connection between liability and fault was severed, it became easier to accept insurance against liability. (Today, let us not forget, liability insurance is often required by law.) And once liability insurance was widely available, judges openly stated that this was a relevant factor in deciding whether tort 
liability should be imposed.

Other factors affected tort liability in a more indirect way. Since the eighteenth century, new mathematical tools and new technologies have been developed to gather and analyse vast amounts of information. This intellectual development, which Ian Hacking called the 'emergence of probability' ${ }^{11}$ has transformed the way people perceive the world. If beforehand events were considered in isolation, the result of a single causal path, the advent of statistics and probability meant that particular events were increasingly considered in terms of their place within wider trends. The effect of this has been to turn individual instances of death, disease, crime or accident into social problems, requiring some kind of comprehensive response, which many felt only the government could provide. The availability of statistics affected tort law in another indirect way: it meant that even without physical harm, statistical data could affect the value of property, a person' s prospects of employability and so on. These new kinds of loss encouraged the development of new doctrines or the updating of old ones.

Alongside these scientific developments there were also political changes that affected tort law. Of the greatest importance is the advent of the modern welfare state and its enormous growth. The welfare state took it upon itself to inspect and regulate many aspects of people' s lives, especially in the areas of physical and economic health and security. In New Zealand such ideas have resulted in the adoption of a social insurance scheme against accidents. In other countries their greatest impact has been to expand the tort liability of public authorities. In other contexts the expansion of welfare provisions meant that tort rules now existed within a different normative environment. Finally, the growing prominence of human rights discourse, including the more controversial social and economic rights, has had a profound impact on the normative background against 
which tort law operates, which in various contexts has broadened the scope of considerations taken into account in determining tort liability. ${ }^{12}$

There are many other factors that have led to expansion in tort liability, but I focus on the ones singled out here because not only do they explain the expansionary trends in tort liability, they also undermine the view that the resolution of a tort dispute can be limited only to factors that pertain only to the litigants: statistical information is inevitably based on a large number of events; insurance pools together many different individuals; deterrence seeks to use tort litigation to change the behaviour of others; the social costs of accidents are a public concern; human rights and the welfare state are topics that belong to public law and policy. When taken together it is not difficult to understand why tort law today is so different from what it was 150 years ago, and how misleading it is to think of it as a strictly 'private' law affair.

As already mentioned, these trends have not been uniformly welcomed, and in recent years several judges and academic commentators have called for a return to a more 'traditional' understanding of tort law. ${ }^{13}$ Though many of them have couched their arguments in terms of the nature of tort law, these authors have had to concede that it is possible to have a different kind of tort law from the kind they favour. Thus, despite appearances they have ended up defending their view by appealing to normative considerations such as separation of powers or the institutional capacity of courts. Quite often these writings have also conveyed a thinly veiled political ideology. ${ }^{14}$ The result is that much of tort law has begun to look 'public' in at least two senses: as a matter of fact, decisions on the scope of tort liability are affected by a myriad of factors not confined to the parties involved in litigation, and as a matter of normative theory, questions of the scope of liability are the subject of competing political theories. 
All these developments, however, do not appear to have had much impact on the intentional torts dealing with harms to the person and to property. ${ }^{15}$ These torts, it seems, have continued to exist as relics from a very different past, a shrinking and little loved island of private law in constant danger of being completely submerged under the rising seas of the more openly public negligence law. ${ }^{16}$ Indeed, it may be that it is exactly because they were perceived as uniquely 'private' that these torts were thought incapable of adapting to novel situations and were therefore left behind. Because of the sorts of events they traditionally covered they were not subject to the kind of evolutionary pressures that led to the doctrinal innovations which enabled negligence to become a versatile tool for dealing with a wide range of new types of situation. Consequently, even issues like patients' consent to medical treatment, which might have been more 'naturally' dealt with under the heading of battery, ended up being treated as cases of negligence. ${ }^{17}$

\section{THREE UNSUCCESSFUL ROLES FOR THE INTENTIONAL TORTS}

All of this raises the question, What role should the intentional torts play within today' $\mathrm{s}$ tort law regime? If for all practical purposes all cases of trespass can also be claimed under negligence, then, despite their unquestionably separate history, we would have to conclude that the intentional torts are now redundant and should be abandoned. Some may have linguistic qualms about intentional actions being treated as cases of 'negligence' ,18 but this should not be a matter of grave concern. If necessary, we could rename negligence as 'unlawful infliction of harm' and thus resolve this problem. But before we move to do so we should examine whether there is no way of understanding the intentional torts that does 
not subsume them under negligence. I will consider three possible interpretations. Common to all of them is the fact that they aim to locate the unique features of the intentional torts within the narrow 'private' law relationship between claimant and defendant. I will argue that for different reasons none of them is satisfactory.

\section{A. Intention as a Special Mental State}

According to one possible interpretation, what justifies separating the intentional torts from negligence is that intention is a unique mental state that cannot be equated with or reduced to mere prediction or indifference (let alone the lack of mental state that is often the mark of negligence), and therefore deserves special treatment by the law. In this sense what distinguishes actions done 'with intention' is that they involve a clear choice on the part of the agent. ${ }^{19}$ John Finnis, who defended the moral significance of this distinction, has argued that the difference is the result of the

impact of choosing and intending upon the character of the chooser $\cdots$ [because] choices last. The proposal which one adopts by choice in forming an intention, together with the reasoning which in one' s deliberation made that proposal intelligently attractive, remains, persists, in one' $\mathrm{s}$ will $\cdots$ The proposal (and thus the intention) is, so to speak, synthesized into one' s will,

one' s practical orientation and stance in the world. ... Whatever consequences lie outside one' s proposal, because neither wanted for their own sake nor needed as a means, are not synthesized into one' $\mathrm{s}$ will..$^{20}$

Though couched in somewhat mysterious terms, Finnis' s point seems clear enough and 
corresponds with widely shared views. The intended outcomes of one's actions are what one strives for, and as such they are properly described as 'owned by' or 'belonging to' the agent. They are so much a part of the agent' $\mathrm{s}$ identity that as far as blame goes we often care little whether the intended outcome materialised or not. Unintended consequences, on the other hand, do not usually reflect on one' s personality in such a way. The difference between acts of intention and the outcomes of negligence is considered so fundamental that it is not surprising that even in jurisdictions where liability for (some types of) accidents is strict or absolute, there is typically an exception for the intentional infliction of harm.

There is a straightforward argument that could support maintaining this distinction in tort law: if we accept the assumption that, other things being equal, acts done with intent to cause harm are more morally heinous or more dangerous (because they are more likely to cause harm) than those that are not, then a heightened mental element could be offset by lowered requirements in the physical elements of the tort. In this way we could capture certain undesirable behaviours that would otherwise escape tort liability. There are traces of this approach in the law: first, the concept of duty of care, which serves as a filtering mechanism for limiting liability for negligence, has no equivalent in intentional torts dealing with similar harm: compare the requirement for a 'special relationship' in the case of negligent misrepresentation with the lack of such a requirement in the tort of deceit. Second, in the case of intended outcomes there is a narrower scope for doctrines like novus actus interveniens, because, as the saying goes, intended consequences can never be too remote. ${ }^{21}$ And third, the limits on recovery for pure economic loss and pure mental injury are much narrower in the case of torts of intention; 22 in fact, certain intentional torts, such as deceit or inducing breach of contract, deal almost exclusively with 
pure economic losses, ${ }^{23}$ whereas similar actions committed without intention often do not give rise to tort liability at all.

This could be a coherent and plausible basis for distinguishing between intentional torts and negligence. It received its clearest endorsement in English law in Letang $v$ Cooper, where Lord Denning drew a distinction between negligence and trespass based on their mental element. As he put it, a claimant must show that he has been harmed either intentionally or negligently. If intentional, it is the tort of assault and battery. If negligent and causing damage, it is the tort of negligence.' ${ }^{24}$ However, as in many other instances, Lord Denning' s view found few supporters. Already in Letang Diplock LJ favoured the view that trespass is not limited to actions committed with an intention to cause harm, ${ }^{25}$ and subsequent cases followed his view. Perhaps it is the expansion of negligence and the decline of the doctrine of privity in contract that has made the need to define the intentional torts in this way seem less pressing.

\section{B. The Intentional Torts as Strict Liability Torts}

We can identify a second way of distinguishing between negligence and the intentional torts, which, perhaps paradoxically, takes a diametrically opposed approach. Contrary to the approach that sought to locate the distinction in a heightened mens rea requirement for the intentional torts, the second interpretation distinguishes the intentional torts by having a lower mental requirement. On this view the difference between negligence and the intentional torts might be characterised in the following way: while the net of negligence is cast very wide to cover a broad range of potential kinds of interaction between individuals, the scope of liability is limited by the need to show negligence on the 
part of the injurer; by contrast, the intentional torts are considerably narrower in the sorts of events they cover, but require a less demanding mental element.

A linguistic basis for such an interpretation of the intentional torts might be based on the distinction between acts done 'intentionally' and those done 'with intent (to bring about a certain outcome)' . If I hit someone while driving, the actions involved in my driving that lead to the accident (turning the steering wheel, pressing on the accelerator) are intentional even though I may have no intention of harming anyone. The former is, to use John Searle' s terms, an example of 'intention in action' while the latter is a case of 'prior intention' .26

A rather strict version of this distinction may be gleaned from several seventeenth century cases of trespass. Two cases of trespass to land maintained that a person commits the tort even when his entry onto another' $\mathrm{s}$ land is the result of a reasonable mistake, ${ }^{27}$ but that a person is not liable if his entry onto another' $\mathrm{s}$ land was involuntary. ${ }^{28}$ Similarly, in the context of trespass to the person one case held that one who directly harmed another could not escape liability 'except it may be adjudged utterly without his fault. As if a man by force take my hand and strike you $\cdots ' 29$ Though couched in the language of fault, the example suggests that only lack of voluntariness would have exempted the defendant. A more recent case that may reflect a somewhat similar view is Wilson $v$ Pringle, where the court said that it is 'the act and not the injury which must be intentional. An intention to injure is not essential to an action for trespass to the person. It is the mere trespass by itself which is the offence.' 30 On this view even an instinctive reaction may be intentional. The difficulty with this approach, however, is maintaining a viable distinction between trespass to the person and a rather broad tort of negligence (at least where physical harm is concerned). Ashley provides a useful illustration. Both the Court of Appeal and the 
House of Lords had to consider the scope of self-defence where a person mistakenly believes he is being attacked. The courts considered three possible rules: (1) one is entitled to defend oneself so long as one' s actions are based on a genuine (even if unreasonable) belief that one is under attack; (2) the defendant is entitled to the defence so long as his mistaken belief is reasonable; (3) the defence is limited to cases of actual attack (and the defence is denied altogether in cases of mistake).

In both courts the unanimously adopted rule was the second one, ${ }^{31}$ although some of the Law Lords made some obiter remarks which were sympathetic to the third rule. ${ }^{32} \mathrm{Had}$ this alternative rule been adopted, trespass to the person could have been defended as a strict liability tort, for even in those instances in which one was in no way to blame for attacking someone else, one would sometimes commit battery. ${ }^{33}$

The distinction matters in those cases in which both sides are innocent but one person' s actions cause harm to another. In negligence the loss in such cases remains uncompensated, whereas in strict liability torts the loss is shifted to the defendant. The rule on self-defence adopted in the Court of Appeal and left unchallenged in the House of Lords was that a reasonable mistake about being attacked would still excuse one in attacking others. This introduces into the tort those flexible elements that have made negligence such fertile ground for development and expansion, but this result is achieved by blurring the distinction between trespass and negligence.

Despite the fact that introducing a standard of reasonableness into the tort of trespass creates this possibility, there was no serious attempt to justify the choice of rule. All we are told is that the rule is justified by the different aims of criminal law and tort law: while criminal law is concerned with protecting against behaviour that is "damaging to the good order of society' , tort law is concerned with 'protecting the rights that every person is 
entitled to assert against $\cdots$ others'.${ }^{34}$ In a moment I will deal with the suggestion that tort law is concerned with the protection of rights, but even if one accepts this view, it is not clear that this calls for a different 'balance' in tort law and criminal law. On the one hand, criminal defendants already enjoy procedural protections not given to their civil counterparts, which may render different substantive rules undesirable. On the other hand, as already mentioned, by adding the reasonableness requirement to a defence of battery, the point of maintaining a distinct tort of trespass to the person becomes less clear. In other words, the decision maintains a particular balance between tort law and criminal law at the expense of undermining a different one within tort law. One may think it desirable that for the sake of maintaining a distinction between criminal law and tort law there should be tort liability even in some cases where there would not be corresponding criminal liability; it does not follow that this liability should be in battery. Thus, one effect of Ashley that has not received much attention is how a decision that seemingly sought to maintain the contemporary relevance of battery did so by eroding the distinction between battery and negligence.

However, from a broader perspective that takes the whole of tort law into view, this result may have been entirely understandable and even justified: if the intentional torts had been interpreted as strict liability torts, that would have meant that when both parties are innocent the loss would be borne by the defendant; by contrast, in negligence in such cases the claimant would normally lose. Given the ubiquity of interactions that could potentially constitute trespass to the person (and, importantly, for which individuals could not adequately insure themselves), it is understandable why the courts would seek to narrow the scope of strict liability intentional torts. In order to achieve this end, many of the traditional torts (including the intentional torts) have been undergoing a process 
which makes them increasingly similar to negligence. In the case of battery, for example, this was done by deciding that the tort does not cover 'all physical conduct which is generally acceptable in the ordinary conduct of daily life' .35 The decision in Ashley is just another manifestation of the same trend. Once again, however, such trends force upon us the question whether there is any unique role for the intentional torts.

In sum, while the strict liability interpretation of the intentional torts could provide a plausible basis for a distinction between these torts and negligence, we see that the courts go against it exactly because of the perception that the intentional torts are a blunt tool for dealing with the many kinds of interactions that are part of everyday life. The result is that this interpretation of the intentional torts is, like the first one, ultimately not likely to succeed in maintaining a significant role for these torts.

\section{Intentional Torts as the Foundation of Primary Rights}

Perhaps, however, considering the question as one of finding normative space for the intentional torts alongside negligence is the wrong approach to take. Perhaps the role the intentional torts play within the legal system is altogether different. Adopting an expansive view of the intentional torts (closer, that is, to the second interpretation considered above), some writers have suggested that the role of the intentional torts is to 'vindicate' people' s primary rights whose content is, roughly, that one is entitled to have control over one' $\mathrm{s}$ body and property and to be free from interference with them. This view is usually associatedwith the 'privatelaw' approachtotortlaw. ${ }^{36}$

Several statements in Ashley indicate that the judges believe that vindication of rights is one of the main purposes of tort law, ${ }^{37}$ and these statements may suggest that this is the true 
reason for maintaining the intentional torts. In fact, however, the picture is more complicated than it at first appears, because the notion of vindication is ambiguous; it can be interpreted in several different ways, not all of which support the private law view. My argument in this section is that two private law interpretations of the idea of vindication are unconvincing, and that the best interpretation of the notion of vindication, at least as found in Ashley, actually fits bettera 'publiclaw' conception of tortlaw.

The notion of vindication can be understood, first, as a 'private' power an individual has to assert the existence of her rights against other individuals (including the state). Alternatively, it may mean an individual' s power to make public the fact that her rights (whose content is determined elsewhere) have been infringed. Importantly, in the former sense the idea of vindication is understood as constitutive of certain relations between individuals; in the latter, the vindicatory (as opposed to the compensatory) role of tort law is in providing a public forum in which claims of infringement of rights are to be both examined and, where a violation has been found, protected by the state. The former interpretation is the one favoured by proponents of the private law view of tort law and will be discussed in this subsection. The alternative, public law version of vindication will be considered in the next section.

The private law notion of vindication is itself ambiguous between two possible interpretations: abstract and concrete. Understood abstractly, tort law may be thought to establish such rights as freedom of speech, bodily integrity, property, autonomy and so on. Thus, for example, it has been suggested that ' $[\mathrm{t}$ ]respass vindicates the rights of property owners to exclude others from their land [and b]attery describes the obligation owed by all citizens to each other citizen not to beat, wound, or inappropriately touch another intentionally and unjustifiably' .38 Along those lines Donal Nolan has suggested that 
negligence may be used to vindicate rights, such as the right to education..$^{39}$

Do we need to use tort law for this purpose? Traditionally, the common law has not protected primary rights by means of positive declaration, ${ }^{40}$ and so tort law has often been the only means to infer 'backwards' the existence of certain primary rights from the existence of legal responses to their violation. The fact that the intentional torts are per se torts, and thus not subject to certain limits imposed on negligence claims, has often been offered in support of the view that one of their roles is to constitute primary rights. Even though the prospects of people bringing claims for violations of their primary rights when they have not suffered harm are small, these torts serve as the legal placeholders for the existence of those rights. They are 'placeholders' because the rights established through them (say, private property or freedom of speech in the abstract) are separate from the question of their protection in individual cases.

In this sense, English tort law has arguably not been a success story. ${ }^{41} \mathrm{~A}$ lack of (if nothing else) the rhetorical force of a positive declaration of rights may be part of the reason why English law is a relative latecomer in respect of many issues on which other legal systems (including other common law systems) have gone much further. To be sure, opinions may differ on the matter, and no doubt looking only at the law provides only a partial explanation of what must be in part a product of the British political tradition. Be all that as it may, reliance on the intentional torts, or for that matter on tort law more generally, no longer seems necessary for the sake of vindication of rights in the abstract sense, because the existence of these rights is by now well established in English law from other sources. In fact, often these rights are so well established that it is doubtful whether anyone asked to provide proof of their legal recognition would turn to the intentional torts as evidence. Probably first among those are societal attitudes toward such matters, 
which, though vague, seem rather firm with regard to many of those rights the intentional torts are supposed to vindicate at the abstract level. Such societal attitudes are known to have an impact on the political underpinning or, if you will, the ideology of a legal system, ${ }^{42}$ and it is doubtful whether without such support legal recognition of these rights would remain intact.

Even within the narrower bounds of more traditional legal materials there are ample sources for the vindication of rights in the abstract sense, first among them criminal law. True, criminal law gives individuals only a limited role in the proceedings and therefore only a limited power to demand the vindication of their rights, but this does not affect the abstract sense of vindication we are concerned with at the moment. So long as the criminal law system functions reasonably well, individuals can point to, say, the many crimes concerned with the protection of private property, bodily integrity, security and so on as constitutive of their rights. Furthermore, as already pointed out, since very few people would (and could afford to) sue in tort law just for the sake of vindication of their rights, the practical difference between criminal law and tort law in this respect is rather minor. So long as it is the symbolic vindication of abstract rights that we care about, then criminal prohibitions seem just as capable of providing it, in some sense perhaps even better than tort law. The developed distinction within criminal law between justifications and excuses implies that in the case of a successful excuse the defendant will be exonerated from criminal responsibility even though the legal system could still acknowledge that another person' s rights have been infringed. Thus, to use Ashley as an example, there is no problem in saying that Ashley' s rights have been infringed by PC Sherwood' $\mathrm{s}$ actions, even if the latter' s actions are found to be excusable. Tort law, which lacks this distinction, fares worse in this regard. 
An additional source for the vindication of rights available since 2000 is the Human Rights Act 1998. Together with the European Convention on Human Rights it provides an additional source of positive declarations about many of the very rights the intentional torts may be supposed to vindicate (as well as some rights whose recognition in English tort law has been patchy at best). ${ }^{43}$

It might be countered that criminal law or the Convention cannot fulfil the role of tort law, because they deal in the relations between individuals and the state, and not with the rights and duties individuals have towards each other. But this is a mistake, which stems from confusing the abstract and concrete senses of the idea of vindication of rights: in the abstract sense it is rights like bodily integrity or freedom of speech that we seek to vindicate. And in this sense criminal law and human rights declarations are sufficient. Even if we think that murder or rape are public wrongs, when we consider what makes them public wrongs, part of the answer is that they violate individuals' rights. In the context of the Convention there is by now a familiar body of law which establishes that states' obligation to 'protect' human rights imposes on the state positive obligations to prevent violations of individuals' rights by third parties. These obligations make sense only if the Convention is a source of legal rights and duties of individuals against each other. $^{44}$

Here is another way of making this point: suppose tort law were to be abolished completely and replaced by an extensive social insurance mechanism while leaving the rest of the law intact. Would we say that our right to bodily integrity has been abolished? In the abstract sense the answer is 'obviously not'. In fact, such a change in the law may be justified by showing that the new legal regime would better protect individuals' rights. Whether or not this is true is an empirical question, not a conceptual one. 
If, despite all this, we believe that for whatever reason tort law is needed for the vindication of rights in this abstract sense, then negligence could provide as good a source within tort law for this purpose. Indeed, it is exactly the flexibility of negligence that allows it to be expanded to cover all sorts of rights (such as the right to education that Nolan had in mind) that would be very difficult to recognise through the intentional torts. Some have suggested, however, that it is only the intentional torts that vindicate rights like bodily integrity or autonomy, and they can do so exactly because the claimant does not need to show harm or unreasonableness on behalf of the defendant. This, it is further argued, shows just how important those rights are. ${ }^{45}$ Even here, however, the flexibility of negligence enables courts to take into account the bodily integrity and autonomy of individuals not only as potential victims, but also as potential injurers. Individuals' autonomy might be undermined not just by physical intrusion by other individuals, but also by overbroad legal limitations on their actions. Vindication of physical integrity through a broad tort of trespass to the person could undermine people' $\mathrm{s}$ autonomy if innocuous trifles that cause no harm could constitute a tort. As we have seen, such consequences were avoided by incorporating elements of reasonableness into the intentional torts.

So, in the abstract sense, the idea that tort law, or more specifically the intentional torts, are required for the vindication of the existence of rights is unnecessary. Perhaps, however, the rights vindicated should be understood differently, ie as establishing the boundaries between activities that lead to tort liability and those that do not. In some writings by defenders of the private law model of tort law we see the view that it is not (just) broad and abstract rights like freedom of speech or bodily integrity that tort law is concerned with. Rather, the rights in question take the form of the right not to suffer 
psychiatric harm by means of negligently causing harm to oneself, or the right not to suffer psychiatric harm by witnessing the immediate aftermath of physical harm suffered by one' s spouse as a result of another' s negligence. ${ }^{46}$ At least in some of the instances in which the courts have spoken of vindication of rights, it appears that it is this sense they had in mind. ${ }^{47}$

On this view, my arguments so far have been wide of the mark, because they misunderstand the role of tort law in vindicating rights. Tort law is required in this sense in order to make concrete the boundaries of abstract rights, something that declaratory documents cannot do precisely because of their generality. On this view there is no space between the existence of a right in a concrete situation and its vindication by tort law, and so at no point in the process does tort law vindicate any rights whose existence is determined elsewhere. ${ }^{48}$ Put differently, in the abstract sense the relationship between tort law and vindication is justificatory; the existence of a right (not itself 'established' by tort law) gives reason to vindicate it through tort law. In the concrete sense, the relation is conceptual. Whenever tort liability is imposed, this means that a right has been violated; whenever tort liability is not imposed, this means that a right has not been violated.

The main difficulty with vindication in the concrete sense is that to say that tort law vindicates rights is to state a tautology. ${ }^{49}$ In this sense the view that tort law vindicates rights is thus trivially true, but in this sense it cannot carve out any distinct conception of tort law. All accounts of tort law, including those thought to be opposed to the private conception of tort law (such as economic interpretations of tort law), are consistent with it. Any liability whatsoever can be phrased as liability for a violated right. For example, by itself this view is consistent with the view that we have a right not to suffer loss at the hands of another, a right not to suffer loss when the costs of eliminating it are lower than 
the expected loss itself, a right not be humiliated in public, or a right to be rescued by others when in danger. This is because in the concrete sense the notion of vindication is by definition devoid of any justificatory force.

\section{A PUBLIC ROLE FOR THE INTENTIONAL TORTS}

Had we only considered the idea of vindication of rights in these senses, we would have had good reason to doubt the point of retaining the intentional tort of trespass to the person, and a fortiori the outcome of Ashley. ${ }^{50}$ This would not necessarily have meant that an injurer' s state of mind had no role to play in tort law. We could still maintain the normative significance of the distinction between intentional and careless acts, and proof of intention could still play a role, for example, in the determination of damages (an approach largely unrecognised in English tort law, but more common in other jurisdictions). This, however, would hardly provide a reason for retaining separate intentional torts. First, under no account do the cases that justify punitive damages track accurately the distinction between intentional torts and negligence: there are many instances of intentional torts which would not call for such damages; and there may be-at least on some justifications of punitive damages - good reasons to award them in some cases of negligence. ${ }^{51}$ Second, even if we thought that proof of intention were a relevant factor in deciding whether to award punitive damages, this would not require separating intentional torts from negligence. Proof of intention to cause harm could then be treated as an aggravating factor, relevant, necessary or sufficient (as the case may be), within other torts.

Is there nonetheless a way of understanding what was decided in Ashley? I think there is, 
but it calls for a different interpretation of the decision in both the Court of Appeal and the House of Lords, one based on some elements in those judgments that have been neglected in previous commentary on the case. On this view one of the points of contention in the case, and one that cuts across the majority-dissent lines in both courts, deals with the potential public role of tort law and of the intentional torts in particular. This view is consistent with something like the idea of vindication of rights appearing in the decision, although only if understood differently from the more familiar 'private law' interpretation. In this sense vindication of a right is not synonymous with recognition of certain legal relations between individuals. Rather, vindication is understood as a particular aim of tort law (or perhaps more specifically tort litigation), and it is to provide $a$ public and impartial public forum for declaring that a claimant' s rights (whose legal origin must be established on other grounds) have been infringed..$^{52}$

Understood in this way, vindication may not seem at first particularly novel or exciting. Arguably, this has been the role of courts from their earliest days. Vindication through tort law in this sense is public in that it requires the existence of a public body funded by the state for its existence, but that seems true of all tort cases. Moreover, since it is legal rights we are concerned with, this view is, once again, consistent with any substantive theory of what the content of those rights should be.

In this sense, then, the public sense of vindication seems not much more illuminating than the private one. Even in this sense, I think it tells us something important, namely that the idea of 'private law' is in some sense incoherent so long as state institutions (be they the legislature or the courts) are involved in both the promulgation of rights and their protection. However, it would be a mistake - indeed, a very similar mistake to the one committed by proponents of the private law view - to think that something follows 
from it regarding what the content of tort law should be.

If that is the case, we are again faced with a puzzle: the courts in Ashley did let the claim in trespass to the person proceed to trial, and they relied on the notion of vindication in reaching this conclusion. What did they mean by that? I want to suggest that at least some of the judges involved in this case used the language of 'vindication' in a distinct sense, quite different from its interpretations considered so far. For them the decision to allow the claim in trespass to the person to proceed to trial was based on their wish that potential misconduct by public authorities be investigated and pronounced upon in a public forum. Thus, in this sense the vindication in question was 'public' not merely in the sense that all law is in some sense public, but in the sense that they were willing to take into account the concerns of the general public not involved in the case in the context of tort litigation. Vindication of rights by tort law is thus not the affirmation of abstract rights or the determination of the boundaries of tort liability. Rather, 'vindication' consists in a finding that a particular individual' s rights have been violated and the recognition that on certain occasions such a finding is of general public significance. If this is correct, what is significant about Ashley is the willingness of the courts to use the machinery of a 'private' law trial for the sake of examining a matter of public concern.

Perhaps the clearest statement of this view is found in Arden LJ's judgment in the Court of Appeal:

The public has high expectations of the police. Like everyone else, the police are subject to the rule of law. Those suspected of criminal activity are entitled to the protection of the law. What the claimants seek in these proceedings is an explanation and redress in a court of law in respect of the 
fatal wounding of James Ashley and its subsequent disclosure to the public. ${ }^{53}$

In this passage Arden LJ focuses on the public interest in knowing what brought about Ashley' s death and the importance of guaranteeing that the police comply with the rule of law. There are indications that this is what troubled some of the other judges hearing the case as well. First, the police admitted negligence in this case all too quickly. After all, if the facts had been as assumed by the court, the police should have stood a good chance of answering a claim not just in trespass, but in negligence as well. If PC Sherwood' $\mathrm{s}$ mistake was reasonable in the circumstances, then it is at least arguable that he was not negligent and that the claim should have been dismissed altogether. Exactly the same considerations that the judges rely on to conclude that there was no trespass to the person in this case (in particular the fact that the decision was made in the spur of the moment and in highly pressing circumstances) can be found in negligence decisions explaining why the defendant did not breach his duty of care. ${ }^{54}$ Why then were the police so quick to admit their negligence in this case? One possibility suggested by the quote above is that the judges suspected that the facts were not exactly as the police claimed them to be. In the Court of Appeal Clarke MR mentioned forensic evidence and some conflicting accounts given by other people at the scene which suggested that the police' s version of the events was inaccurate ${ }^{55}$ he also mentioned evidence regarding Sherwood's problematic disciplinary record, which at one point even led to a temporary suspension of his firearms authorisation. ${ }^{56}$

Alternatively, the negligence was not at the point of execution but rather at the planning stage, ${ }^{57}$ but even in that case it may be in the public interest to know whether there were additional violations of police regulations by PC Sherwood. Either way, it 
appears that an important reason for the courts' decision to allow the trespass claim to go to trial was the need to make the police more accountable to the public for their actions. Sensing that the inquiries into the events that led to Ashley' $s$ death had not been properly conducted but unable to order a public inquiry, some of the judges in both the House of Lords and the Court of Appeal adopted the closest possible alternative to it: they allowed the claim in trespass to go to trial and hinted that they would want to see a more vigorous investigation into what actually happened the night Ashley died. ${ }^{58}$ Thus, this approach is consistent with the vague idea of vindication of rights, and yet (and seemingly paradoxically) it seems to undermine the particular view of tort law usually associated with it. In this sense vindication is quite limited, because the number of cases in which it would be invoked is rather small (in contrast with the private law versions of the vindication argument, in which each tort case, implicitly at least, vindicates rights), but in those cases vindication is of real, practical significance.

This conclusion is important in several respects. Most narrowly, for the sake of understanding the outcome of the case it is worth noting that the different views on this matter were not drawn along the majority-dissent lines. In the Court of Appeal it looks as though the individualistic, private law view prevailed: it was endorsed both by Clarke MR writing for the majority ${ }^{59}$ and by Auld LJ, who explicitly stated that '[t]he claim in battery is a private law claim, the only proper function of which is to provide a private law remedy' .60 In the House of Lords, however, the public law view suggested here seems to have had the support of at least two (and perhaps three) members of the panel, with the views of another (Lord Bingham) not entirely clear on the matter.61 (Only Lord Carswell clearly rejected this view. ${ }^{62}$ ) Lord Scott seemed to approve of the claimants' desire 'to obtain a public admission or finding that the deceased $\cdots$ was unlawfully killed by PC 
Sherwood. They want a finding of liability on their assault and battery claim in order to obtain public vindication of the deceased' s right not to have been subjected to a deadly assault ...' 63 Lord Rodger approved of claimants pursuing tort law claims to the end in order to 'try out another novel, and more doubtful cause of action, $\cdots$ [or] in order to try to establish a point of law which would help others in a similar plight' ${ }^{64}$ And interestingly, the clearest support for this view in the House of Lords can be found in Lord Neuberger' $\mathrm{s}$ dissent, in which he stated: 'I accept $\cdots$ that there is a point in seeking a declaration $\cdots$ because it is reasonable for Mr Ashley' s estate to wish to establish that his death was unlawfully caused and because there is a publicinterestelement in proceeding, 65

But more than head counting, if this reading of the decisions is correct, then it may be that the most important aspect of Ashley is not any of the technical issues that took up most of its pages. The question of mistaken self-defence and the burden of proof in such cases are matters of relatively little practical significance because they arise very rarely (as evidenced by the paucity of cases dealing with these issues). Rather, Ashley is important because it shows the willingness of at least some of the judges in the Court of Appeal and the House of Lords to consciously introduce public considerations into tort law. To put matters more controversially, some of the judges may have used expressions like 'vindication of rights' which are associated with a private law conception of tort law to reach a 'public law' result that broadened judicial inspection of government action.

The significance of the decision lies in its particular understanding of the idea of oversight. Using tort law as a tool for guaranteeing governmental accountability is a relatively novel, but by now not unheard of, idea. ${ }^{66}$ In this way tort law may perhaps already be given a role that goes beyond its traditional scope, but it is one that can be accommodated within the Diceyan conception of the rule of law. What is important about 
the approach of Arden LJ, Lord Rodger and Lord Neuberger is their willingness to consider the interests of the general public, that is, people who were not directly harmed in the incident and who are not represented in the litigation in the context of a tort claim. This willingness on the part of some of the judges to blur the boundaries between private and public law and to give the intentional torts a more public role may also help in understanding the recent resurgence of the 'newly evolving tort' 67 of misfeasance in public office, also considered in Ashley. Originally concerned with voting rights, misfeasance in public office is an intentional tort exclusively concerned with harms resulting from abuses of power by public authorities. This tort lay dormant and little used for many decades, ${ }^{68}$ and its new lease of life may reflect an understanding of a greater need for stronger legal means of controlling government action, and a growing awareness on the part of the judges of the potential for using tort law for this purpose. ${ }^{69}$

Looking to the future, Ashley raises three questions: ${ }^{70}$ the first is whether it will be necessary to rely on the intentional torts for this public role in the future. Could courts in future cases not add this role to the versatile and flexible tort of negligence? Is there anything that gives the intentional torts any advantage over negligence in this context? Admittedly, the reading of Ashley suggested here is consistent with a broader public law role for all of tort law, and so if future courts decide to adopt a similar approach, they might not confine it only to the intentional torts. It may be that even in Ashley the public role given to battery was merely a pragmatic solution to the unique facts of the case. Perhaps it was battery and not negligence on which the 'burden' of public inquiry had been laid only because of the unusual way in which both parties decided to plead their case.

Even if that is the case, however, the decisions in Ashley are not insignificant: the 
police clearly knew that they could end the matter and avoid judicial inquiry into the events that led to Ashley' s death by admitting that their actions amounted to battery, and yet they chose not to do so. In this regard the significant point is not whether other torts could have been (and in the future, might be) used for the same purpose. The point is that the court was willing to use tort law, and specifically the intentional torts, for public purposes.

The second, related, question is how likely it is that the intentional torts would be used for a similar purpose in the future. In part the answer to this question depends on the behaviour of defendant public authorities in future cases. Having learnt their lesson, they might prefer to swallow their pride and admit to battery if only to avoid a potentially more damaging public inquiry in court. On the other hand, it may be that the otherwise unimportant linguistic point about the difference between negligence and intention would prove significant in this context, as public authorities might prefer to have a long inquiry which they might survive relatively intact to a damaging admission of the 'intentional' violation of an individual' s rights.

Apart from public authorities' reaction to Ashley, it remains to be seen how many future courts will be willing to look behind the questions that appear on the surface of Ashley and read it in the way suggested here. Indeed, it may be that the matter was discussed in such vague terms exactly in order to guarantee that the decision in Ashley remains 'a restricted railroad ticket, good for this day and train only' ${ }^{71}$ Moreover, even if some of the judges do wish to expand this approach to courts' inspection of governmental bodies, it may be that Arden LJ' s discussion at the end of her judgment on the effect of European law on future cases ${ }^{72}$ indicates that there will not be much need in the future for the particular technique chosen in Ashley to guarantee oversight of government action, as it may be easier and more natural for the courts to rely on the European 
Convention on Human Rights for this purpose. ${ }^{73}$ On the other hand, it may be that some judges, who may be reticent about the importation of European ideas into English law, ${ }^{74}$ will find this home-grown development more appealing. In any case, here too, the issue is not so much whether future courts will follow Ashley as precedent. What matters more is what this case reveals about the attitude of some of the judges regarding the foundations of tort law, judges whose view is clearly different from what we are told by many commentators is the correct way of understanding (English) tort law. Only a few years before Ashley was decided, the House of Lords, relying on European jurisprudence, emphasised the importance of conducting a public investigation into the unlawful death of a prisoner at the hands of another prisoner in the context of a judicial review, 'public' law case. ${ }^{75}$ In Ashley, ignoring the public-private divide, it allowed the use of English tort law for the same purpose. The decision thus both emphasises within tort law the deterrent role of tort law over its more private, compensatory role; but it can also be seen as part of a broader attempt by the judiciary to strengthen constitutional values such as governmental transparency and accountability, rule of law, and checks and balances. Since some have questioned the capacity of monetary remedies to have an effect on government, ${ }^{76}$ the approach adopted in Ashley may prove particularly fruitful.

The third question is whether the broader development which I have argued is reflected in Ashley is desirable and whether it is likely to be effective. Here the traditional divisions of law may lead some to the conclusion that such inspections of governmental behaviour should not be conducted as part of a tort case, because the purpose of tort law is only to deal with the compensation claims of private individuals as a result of individual wrongdoing. ${ }^{77}$ Put this way, this objection strikes me as very weak. The scope and aims of tort law do not come to us from heaven as commandments to obey, and whatever roles tort 
law currently fulfils should be maintained only to the extent that they serve a purpose. There may be very good reason to distinguish between the private and the public: after all, most people behave differently in private and in public and it is entirely plausible that the law should reflect this distinction in some way. But as the boundaries between private and public life have shifted in the last few decades (due to, among other things, the rise of the welfare state as well as technological changes), it is only natural that the boundaries between private and public law will shift as well. If what has traditionally been classified as public law proves insufficient for inspecting public bodies, courts should not let formal boundaries stand in the way. ${ }^{78}$

However, the objection may be put more forcefully. It may be argued that because historically tort law was conceived as concerned only with private disputes, its substantive rules, as well as the procedural rules of civil proceedings, have developed in such a way that tort law cannot adequately fulfil this new role assigned to it: the judge might not have the experience or expertise necessary to deal with such questions, adversarial proceedings might be thought inferior to a more inquisitorial process needed to deal with such questions, the judge and parties will be operating under certain time or financial constraints that will hamper careful examination of the relevant issues, the concerns of certain relevant parties may not be adequately represented, and so on. This is potentially a formidable challenge, and it is certainly possible that on certain occasions the objection could prove decisive against using tort law for the purposes envisaged here. I do not think, however, that it calls for an outright rejection of the approach presented in this essay. First, there is a long if convoluted history of dealing with public law matters in what are formally private law disputes, so there is no a priori reason to think that judges are incapable of dealing with such matters in the context of private law disputes; second, 
procedural and evidentiary rules of civil proceedings have undergone considerable change in recent years, making claims about the impossibility of adequately handling such claims within the confines of a private law dispute seem less persuasive. The more active role given to judges with the advent of case management gives them a greater ability to turn the parties to the issues and evidence they consider important for the resolution of the case. ${ }^{79}$ Finally, while considerations based on the path-dependent development of the law have their force, they cannot forever block a change in course, if one is needed. If one believes that these rules stand in the way of an otherwise valuable goal, they should be changed.

At the same time, it is clear that the solution found in this case is a makeshift tool, and as such it has its limitations. Not all cases can be brought within the remit of intentional torts, and as we have seen, ultimately the decision as to whether a judicial inquiry will be conducted is in the hands of the defendant. If the police had admitted to battery in Ashley' s case, there would have been no trial, and thus no opportunity for judicial investigation. Anyone concerned about the adequacy of existing mechanisms for inspecting public authorities (and police activity in particular) would surely prefer to see a more comprehensive and direct treatment of this problem.

This leads to another, related, challenge, namely that there is no reason to think that such judgments are going to be an effective means of inspecting governmental action. There is a familiar view, with considerable academic support in the UK, that questions the wisdom of relying on courts to provide an effective check on the excesses of the executive. ${ }^{80}$ Those holding this view would surely doubt that the occasional tort claim could have any noticeable impact on the behaviour of the executive. They may be right; but perhaps, especially when the powers of the executive are constantly expanding while the 
capacity of the legislature to adequately control it is in decline, ${ }^{81}$ and when because of the sheer size and complexity of their operations effective control of public authorities is increasingly difficult, what is required is a willingness to consider new means of supervising public authorities.

\section{CONCLUSION}

Looked at from a narrow perspective, Ashley is an unusual case. Judges ordinarily try to avoid deciding on matters that have no effect on the outcome of the case. Their reasons for doing so are easy to understand and for the most part entirely justified. There is no point spending time and effort on deciding 'academic' questions when time and money are limited and there are so many other cases awaiting resolution. The case is also interesting because it goes against recent trends that have tended to be quite restrictive with regard to tort liability of public authorities. (Even though most of these decisions involved liability for negligence, many of the policy considerations relied upon against the imposition of liability are applicable to other torts as well.) Why, then, did the majorities in the Court of Appeal and House of Lords agree to let the question of whether James Ashley’ s person had been trespassed go to trial?

This puzzle calls for explanation. In this article I have considered several 'individualistic' readings of the intentional torts. Some, like the view that the intentional torts should be limited to acts done with intention, focus mostly on individual injurers; others, like the view that the intentional torts should be concerned with vindication of 
rights (in its traditional understanding), focus on individual victims. I have argued that if we try to limit the ruling in Ashley to these interpretations, then the decisions of both the Court of Appeal and the House of Lords are difficult to defend.

Instead I suggested that we should look beyond the parties involved in the case; then a different picture emerges. On this picture the tort of trespass to the person was allowed to go to trial for the sake of making public authorities accountable for their actions. Lord Mustill once indicated that in order to 'avoid a vacuum in which the citizen would be left without protection against a misuse of executive powers the courts have had no option but to occupy the dead ground in a manner, and in areas of public life, which could not have been foreseen 30 years ago' .82 If my analysis is correct, Ashley is most convincing as reflecting a similar attitude. Over the years English courts have often been accused of tending to be overly deferential and uncritical towards public authorities and particularly the police, ${ }^{83}$ and recent examples show that this attitude may not simply be a thing of the past. ${ }^{84}$ This attitude might have been justified had public trust in the police been high, but revelations of police impropriety that was later covered up led one newspaper to report that ' $[\mathrm{t}]$ he incident undermines confidence in the accountability at the police department'. 85 Rather than concerns over an excessively defensive police force as a result of the imposition of liability, such incidents indicate that there are reasons to be concerned about an overly aggressive police force, and that part of the problem may be insufficient judicial oversight. ${ }^{86}$ Some of the opinions in the Ashley decisions reflect a recognition of these problems and a willingness to develop new methods of dealing with the vacuum that has allowed such events to happen. 


\section{Notes}

* Assistant Professor, Osgoode Hall Law School, York University, Toronto, Canada. I thank Peter Cane, Bill O' Brian and Jane Stapleton for comments on an earlier, and quite different, version of this essay. I also thank James Harrison, Alicia Hinarejos, Cathryn Costello and Victor Tadros for clarifications on issues relating to this essay. Finally, thanks are due to Satvinder Juss and Jeremy Horder, and to the anonymous referees of King's Law Journal for their comments.

2 Ashley $v$ Chief Constable of the Sussex Police [2006] EWCA Civ 1085, [2007] 1 WLR 398 (CA) (hereinafter Ashley-CA); Ashleyv Chief Constable of Sussex Police [2008] UKHL 25, [2008] 1 AC 962 (hereinafter Ashley- HL or Ashley).

3 Phil Palmer and Jenny Steele, 'Police Shootings and the Role of Tort' (2008) 71 Modern Law Review 801,810 - 11; Nicholas J McBride, 'Trespass to the Person: The Effects of Mistakes and Alternative Remedies on Liability' (2008) 67 Cambridge Law Journal 461, 462; Robert Stevens, 'The Conflict of Rights' in Andrew Robertson and Tang Hang Wu (eds), The Goals of Private Law (Hart Publishing, 2009) 139, 163.

4 See eg Robert Stevens, Torts and Rights (Oxford University Press, 2007) 3.

5 See, for example, the way in which Page v Smith [1996] AC 155 was distinguished in Grieves v FT Everard $\mathcal{E}$ Sons Ltd [2007] UKHL 39, [2007] 3 WLR 876.

6 This approach reached absurd levels when Lord Hoffmann speculated in Stovin v Wise [1996] AC 923, 958 (without a shred of evidence) that one possible outcome of Anns v Merton London Borough Council [1978] AC 728 was that 'local council inspectors tended to insist upon stronger foundations than were necessary' .

7 That is, for example, how Baker v Willoughby [1970] AC 467 (HL) was treated in Jobling v Associated Dairies [1982] AC 794, 809 (HL). See also Williams v Natural Life Health Foods Ltd [1998] 1 WLR 830, 837 (HL), in which Lord Steyn circumvented Smith v Eric S Bush [1990] 1 AC 831 (HL) by saying that it was 'decided on special facts' .

8 Hunterv Canary Wharf [1997] AC 655 (HL).

9 'Rewriting' is not my word. It is how Lord Rodger described (in his dissent in Barker v Corus UK Ltd [2006] UKHL 20, [2006] 2 AC 572, [71]) the majority' s treatment of McGhee $v$ National Coal Board [1973] 1 WLR 1 (HL) and Fairchild $v$ Glenhaven Funeral Services Ltd [2002] UKHL 22, [2003] 1 AC 32. The rewriting of McGhee arguably began earlier, when Lord Bridge said that McGhee 'laid down no new principle' : Wilsher v Essex Area Health Authority [1988] AC 1074, 1090. Lord Rodger rejected this statement when he said that 'McGhee undoubtedly involved a development in the law relating to causation' : Fairchild [2003] 1 AC 32, [154].

10 Murphyv Brentwood District Council [1991] 1 AC 398; cf O'Rourkev Camden London Borough Council [1998] AC 188, which rejected (as obiter) part of Cocksv Thanet District Council [1983] 2 AC 286.

11 Kenneth S Abraham, 'The Rise and Fall of Commercial Liability Insurance’ (2001) 87 Virginia Law Review $85,86-87$ and fn 6.

12 Ian Hacking, The Emergence of Probability: A Philosophical Study of Early Ideas about Probability, Induction and Statistical Inference (Cambridge University Press, 2nd edn 2006); see also Gerd Gigerenzer et al, The Empire of Chance: How Probability Changed Science and Everyday Life (Cambridge University Press, 1989) 260 ( 'statistics and probability have modified key legal concepts like negligence, liability, and intent' ).

13 For example, recent defamation decisions show a growing recognition of the significance of freedom of speech and information. Discussing these matters 'would probably have astonished most of the Law Lords who considered libel appeals in the course of the preceding century. They developed the principles of defamation law, without generally much attention to the implications of their decisions for freedom of the speech and of the press' . Eric Barendt, 'Libel, Privacy, and Freedom of Expression' in Louis Blom-Cooper et al (eds), The Judicial House of Lords: 1876-2009 (Oxford University Press, 2009) 653, 653.

14 See eg Stevens (n 3); Allan Beever, Rediscovering the Law of Negligence (Hart Publishing, 2007); Nicholas J McBride and Roderick Bagshaw, Tort Law (Longman Pearson, 3rd edn 2008).

15 See Dan Priel, 'Torts, Rights, and Right-Wing Ideology' (2011) 19 Torts Law Journal 1.

16 Which torts actually fall under the heading 'intentional torts' is not entirely clear. Cf Ken Oliphant, 'The Structure of the Intentional Torts' in Jason W Neyers et al (eds), Emerging Issues in Tort Law (Hart Publishing, 2007) 509, 512 - 13 for a suggested list. Even though some of the trends I discuss can be found in many of those intentional torts, in this essay, unless I indicate otherwise, I use 'intentional torts' as shorthand for trespass to the person (assault and battery) and trespass to land.

17 Cf Peter Cane, 'Mens Rea in Tort Law' (2000) 20 Oxford Journal of Legal Studies 533, 534 - 5, 552 - 3 (arguing that the intentional torts have become marginal). To see just how unused these torts are, consider the fact that in Ashley, a case decided in 2006, the Court of Appeal engaged in a lengthy discussion of the question of burden of proof in the tort of trespass to the person. See Ashley-CA, [19] - [33].

18 See Sidaway v Board of Governors of the Bethlem Royal Hospital [1985] AC 871, 894, and additional sources cited in Ian Kennedy and Andrew Grubb, Medical Law (Butterworths, 3rd edn 2000) 581.

19 See eg Peter Cane, 'Justice and Justifications for Tort Liability' (1982) 2 Oxford Journal of Legal Studies 30, 38 
( 'There is, no doubt, a resistance to treating intentional harms generally as if they were merely negligent, if only on linguistic grounds' ); WVH Rogers, Winfield and Jolowicz on Tort (Sweet \& Maxwell, 18th edn 2010) 140 ( 'one can hardly describe attempted murderas "negligence" ' ).

20 Cf Rogers, ibid, 143 ( 'wicked people are worse than careless people and we should not forget it' ).

21 See John Finnis, 'Intention in Tort Law' in David G Owen (ed), Philosophical Foundations of Tort Law (Clarendon, 1995) 229, 243 - 4. Finnis claims that this is 'a real, empirical $\cdots$ effect of one' s adopting a proposal' (244). Psychological studies, however, suggest that the ascription of intention is morally loaded. See Joshua Knobe, 'The Concept of Intentional Action: A Case Study in the Uses of Folk Psychology' (2006) 130 Philosophical Studies 203.

22 eg Amstrad Consumer Electronics v British Phonographic Industry [1986] FSR 159, 198; Quinn v Leathem [1901] AC 495, 537 ( 'The intention to injure the plaintiff negatives all excuses and disposes of any question of remoteness of damage' ).

23 For intentionally inflicted mental injury see Wilkinson v Downton [1897] 2 QB 57. More generally see Lord Hoffmann' s remark in Hunter $v$ Canary Wharf [1997] AC 655, 707 that he saw 'no reason why a tort of intention should $\cdots$ exclude[] compensation for mere distress, inconvenience or discomfort' (although he was somewhat less committed to this view in Wainwright v Home Office [2004] 2 AC 406, [41] - [47]). There are also some cases that were willing to extend liability in nuisance when intention to cause harm was proven. For examples see Christie v Davey [1893] 1 Ch 316, 326 - 7; Hollywood Silver Fox Farm Ltd v Emmett [1936] 1 KB 468, 475. Admittedly, though, there are some well-known counterexamples.

24 In the case of deceit, for example, the claimant needs to show an intention to bring about a certain outcome (that the victim will act on the false information). See Langridge v Levy (1837) 2 M \& W 519, 531; 150 ER 863,868 . If successful, she can recover for pure economic loss.

24 Letang v Cooper [1965] 1 QB 232, 239 - 40; cf Williams v Holland (1833) 10 Bing 112, 117 - 18; 131 ER 848, 851.

25 Letang [1965] 1 QB, 243 - 5. Ironically, Lord Denning said in Letang that he based his decision on an earlier decision of Diplock, Fowler v Lanning [1959] 1 QB 426, even though it did not support his view. In Fowler it was held that there is no difference in the substantive law between trespass and negligence and that proof of negligence is required in both (ibid, 434 - 5). Later cases emphasised the distinction between the two on the basis of the directness of the harm: Wainwright [2004]2 AC406, [8]; Wongv Parkside Health NHS Trust [2001] EWCA Civ 1721, [2003] All ER 932, [7]. However, as all cases of direct harm could be claimed under negligence as well as trespass to the person, this distinction too is unhelpful for giving trespass to the person a significant role.

26 See John Searle, Intentionality: An Essay in the Philosophy of Mind (Cambridge University Press, 1983) $84-85$.

27 See Gilbert v Stone (1647) Sty 72, 82 ER 539.

28 Smithv Stone (1647) Sty 65,82ER 533; also Conwayv GeorgeWimpey E Co[1951]2 KB266,274 (intention to trespass is not required). But see $n 50$ below.

29 (1616) Hob 134, 134; 80 ER 284, 284 (KB).

30 Wilson v Pringle [1987] QB 237, 249 (CA).

31 There is some ambiguity as to the scope of the demand for reasonableness. This is how Arden LJ explained the reasonableness requirement in the Court of Appeal: 'It would have to be shown, in addition to showing that [the person] honestly believed in the material facts, that [his] actions were reasonably necessary for his defence.' Ashley-CA, [206]. This is a somewhat broader formulation of the defence than the one adopted by the other judges in the Court of Appeal and the House of Lords, according to whom both the mistake and the response need to be reasonable. This is significant in the case of a person who genuinely but unreasonably thinks another is about to attack him and then reacts in a way that is reasonable given the unreasonable belief. According to the majority view, that person has no defence, but according to Arden LJ he may have one.

32 Most explicitly Lord Scott in Ashley-HL, [20]. Using somewhat weaker language, Lords Rodger (at [55]) and Neuberger (at [90]) have also not ruled out the possibility of adopting such a rule in the future.

33 Cf Rv Governor of Brockhill Prison, ex parte Evans (No 2) [2000] 3 WLR 843 (HL), where the House of Lords adopted a strict liability interpretation of the tort of false imprisonment, imposing liability on the state in a case in which a mistaken but reasonable calculation resulted in the claimant spending 59 more days in prison than she should have.

34 Ashley-HL, [17] - [18] (Lord Scott). Similar statements were made by the other Law Lords, eg at [3] (Lord Bingham) and [75] (Lord Carswell).

35 Collins v Wilcock [1984] 1 WLR 1172, 1177 (Goff LJ); affirmed in Re F (Mental Patient: Sterilisation); F v West Berkshire Health Authority [1990] 2 AC 1, 72. There are a few exceptions to this development but they are not difficult to explain. In the case of torts that do not pose a significant risk to the delicate balancing act of negligence, the courts were much more willing to adopt a strict liability interpretation of the tort, as the House of Lords did in the false imprisonment case of ex parte Evans (n 33). False imprisonment is a rather rare occurrence, and it is nowadays a tort that most commonly has the state as defendant. The severity of the 
impact of false imprisonment on one' s liberty, the virtual impossibility of insuring against it, the very deep pockets of the state, and - in line with the thesis advanced later in this essay - perhaps also the fear that without imposing such liability the state might be tempted to abuse its powers, all explain why it makes sense to impose liability even in cases of reasonable false imprisonment while narrowing the scope of battery. Indeed, Reeves $v$ Commissioner of Police of the Metropolis [2000] 1 AC 360 shows that in cases involving prisoners we can identify change in the opposite direction, with negligence being stretched towards strict liability.

36 See eg Stevens (n 3) 325, passim. For a case note that interprets Ashley-HL in this fashion see McBride (n 2).

37 eg Ashley-HL, [22] (Lord Scott), [60] (Lord Rodger).

38 John CP Goldberg and Benjamin C Zipursky, 'Accidents of the Great Society' (2005) 64 Maryland Law Review 364,391.

39 See Donal Nolan, 'New Forms of Damage in Negligence' (2007) 70 Modern Law Review 59, 88. Nolan expresses some concern about the limits of vindication through negligence due to restrictions on the types of actionable damages, but this situation is not really different in torts that do not require proof of harm. A nominal right of action is unlikely to be of much use when there is no prospect of monetary compensation.

40 See Michael Lobban, The English Common Law and English Jurisprudence 1760-1850 (Clarendon, 1991) 11 - 13 ; PS Atiyah, Pragmatism and Theory in English Law (Stevens \& Sons, 1987) 18 - 19, 21 - 25. Dicey extolled this approach as part of English law' s conception of the rule of law in his Introduction to the Study of the Law of the Constitution (Liberty Fund, 8th edn 1982 [1915]) 117 - 20.

41 For this view see Tom Bingham, 'TortLaw and Human Rights' in The Business of Judging; Selected Essays and Speeches 1985-1999 (Oxford University Press, 2000) 169; cf Atiyah (n 40) 19 - 21.

42 I use the word 'ideology' non-pejoratively. SeefurtherClifford Geertz, 'Ideology as a Cultural System' in The Interpretation of Cultures (Basic Books, 1973) 193, 196 - 200.

43 See Watkins v Secretary of State for the Home Department [2006] UKHL 17, [2006] 2 AC 395, [64] where Lord Rodger said: "Now that the Human Rights Act 1998 is in place, [the] heroic efforts [to find "constitutional rights" in the common law] are unnecessary: the Convention rights form part of our law and provide a rough equivalent of a written code of constitutional rights ...' See also Ashley-HL, [22] (Lord Scott).

44 Contrary to Stevens (n 2) 146. Cf Campbell v MGN Ltd [2004] UKHL 22, [2004] 2 AC 457, [132] (Baroness Hale) for the suggestion that the Convention may be applicable to private bodies.

45 This is the sense of vindication found in TR Hickman, 'Tort Law, Public Authorities and the Human Rights Act 1998' in Duncan Fairgrieve et al (eds), Tort Liability of Public Authorities in Comparative Perspective (BIICL, 2002) 17, 20, 29; Tony Weir, 'The Staggering March of Negligence' in Peter Cane and Jane Stapleton (eds), The Law of Obligations: Essays in Celebration of John Fleming (Clarendon, 1998) 97, 109 - 10. The practical effect of this view is very similar to the view discussed in section II.(B) above.

46 The former 'right' was not vindicated in Greatorex v Greatorex [2000] 1 WLR 1970 (CA); the latter was vindicated in Alcock $v$ Chief Constable of South Yorkshire Police [1992] 1 AC 310. For an actual example of a concrete 'right' tailored to tightly fit a tort, consider Stevens' claim that 'we have a right not to be told lies we believe' . Robert Stevens, 'Torts' in Blom-Cooper et al (n 12) 629, 635 (emphasis added).

47 This, arguably, is also the use of vindication as understood by Lords Scott and Carswell in Ashley-HL, at [22] and [80] respectively; see also Chester v Afshar [2004] UKHL 41, [2005] 1 AC 134, [87]; cf $M v$ Newham London Borough Council [1995] 2 AC 633, 676 (CA).

48 This is the implication of the view that it is legal rights, and not moral rights, that are vindicated by tort law, a view explicitly adopted in Nicholas J McBride, 'Duties of Care-Do they Really Exist?' (2004) 24 Oxford Journal of Legal Studies 417, $417 \mathrm{fn} 1$.

49 It is only in this sense that Stevens is right when he says that if tort law were to be abolished that would mean 'the abolition of most of our legal rights' (Stevens (n 3) 325). But as in this concrete sense this is a tautological statement, this is no cause for concern. It would by no means threaten individuals' abstract legal rights or their moral rights, which (as explained already) might be better protected if tort law were abolished.

50 Cf Fowler v Lanning [1959] 1 QB 426, 433 - 4, where Diplock J made it clear that it was a mistake to think that in order to escape liability in trespass to the person one 'must comply with any higher standard of care than was needed to escape liability if the action were framed in trespass on the case' , and that 'there does not appear by 1852 to have been any difference between the substantive law applicable whether the action were framed' as one or the other tort. See also David Howarth, 'Is there a Future for the Intentional Torts?' in Peter Birks (ed), The Classification of Obligations (Clarendon, 1997) 233, 266 - 8, 280 (his answer: not really); PS Atiyah,

'American TortLaw in Crisis' (1987) 7 Oxford Journal of Legal Studies 279, 284 - 5.

51 See eg Cento Veljanovki, Economic Principles of Law (Cambridge University Press, 2007) 236 - 7.

52 The distinction between these two senses of vindication is missed in the discussion of Ashley in Jenny Steele,

'Damages in Tort and under the Human Rights Act: Remedial or Functional Separation?' (2008) 67 Cambridge Law Journal 606, 628.

53 Ashley-CA,[189] (emphases added).

54 See eg Marshall v Osmond [1983] QB 1034 (CA); Wilsher v Essex Area Health Authority [1987] QB 730, 749 
(CA). Marshall is particularly relevant as it deals with police error during a chase after a criminal, and the court decided that such an error does not always amount to a breach of duty of care. Cf Keegan $v$ Chief Constable of Merseyside [2003] 1 WLR 2187 (CA), where the Court of Appeal relied on policy considerations to dismiss a claim against the police when it was clearly negligent but its error was judged to have been made in good faith. This decision was overturned in Keegan v United Kingdom (2007) 44 EHRR 33.

55 SeeAshley-CA,[86] - [92],[110]; cf Ashley-HL, [69] ( 'Frequently $\cdots$ adefendantcannotchallenge theinterest of the claimant to pursue the action without simultaneously calling into question his own real interest in defending the action' ).

56 Ashley-CA, [117].

57 At least three of the judges involved in this litigation located the police' s negligence at the planning stage. See Ashley-HL, [54] (Lord Rodger), [91] - [94] (Lord Neuberger); Ashley-CA, [196] (Arden LJ).

58 In this connection it is interesting to compare Ashley with Cullen $v$ Chief Constable of the Royal Ulster Constabulary [2003] UKHL 39, [2003] 1 WLR 1763, which was not mentioned in the Ashley decisions. In a 3-2 decision the House of Lords held that a person who had been wrongfully detained was not entitled to tort damages for the detention when he could not prove any harm. In explaining the majority' $\mathrm{s}$ view McBride and Bagshaw (n 13) 489 fn 39 say that there is no point in allowing a claim 'for the sole purpose of having it established in a public forum whether or not the police acted lawfully in denying him access to a solicitor $\cdots$ [I]t is hard to see what useful purpose would be served in allowing him to do this.' When considered in purely private law terms, this might be true; but if we think of the public role that tort law could play, as I suggest some judges in Ashley did, such a claim may be useful. Indeed, I would contend that the public law reading of Ashley suggested here is closer in spirit to the Cullen dissent.

59 Ashley-CA, [96] ( 'The role of the civil courts is not solely to provide compensation' ; one reason why civil trial exists is 'to determine the parties' legal rights and liabilities' ).

60 Ibid, [178].

61 See also Lord Bingham' s vague comments on the issue in Watkins [2006] UKHL 17, [8] - [10].

62 Ashley-HL, [81].

63 Ibid, [23].

64 Ibid, [70].

$65 \mathrm{Ibid},[110]$ (emphasis added). See also ibid, [114] ( 'there is, at least potentially, a substantial public interest in the outcome of the battery claim' ).

66 See Carol Harlow, State Liability: Tort Law and Beyond (Oxford University Press, 2004) 49 - 53; AM Linden, 'Tort Law as Ombudsman' (1973) 51 Canadian Bar Review 155; Erika Chamberlain, 'Negligent Investigation: Tort Law as Police Ombudsman’ in Robertson and Hang Wu (n 2) 283.

67 R Cruickshank Ltd v Chief Constable of Kent County Constabulary [2002] EWCA Civ 1840, [2002] Po LR 379, [14].

68 The history of the tort, its long fall to obscurity, and its recent re-emergence are detailed in Three Rivers District Councilv Governor and Company of Bank of England (No3) [2003]2 AC 1,29 - 45.

69 Cf ibid, 190, where Lord Steyn considered the significance of the tort in maintaining the rule of law.

70 Another question I will not discuss here is to what extent ideas such as those found in Ashley could be used in contexts involving not the state but, for example, large corporations. There is some judicial recognition of this in Jameel [2006] UKHL 44, [158] (Baroness Hale), but despite their power such bodies raise different considerations from those applicable to governments. It is worth noting that a recent decision that arguably was willing to extend the public rationale of Ashley in the context of litigation between two private parties did so when the case involved an event that was of considerable public significance. See the discussion in Breslin $v$ McKenna [2009] NIQB 50, [4] - [5].

71 This is how Justice Jackson described in a dissent the majority' s overruling of a recent earlier decision: Smith $v$ Allwright (1949) 321 US 649, 669. For those who wish to find it, the escape route is already in Ashley-CA, which Clarke MR described as 'a very unusual case’ . See [160].

72 Ibid, [211] - [214].

73 Cf $R$ (Hurst) $v$ London Northern District Coroner [2007] UKHL 13, [2007] 2 AC 189; In re McKerr [2004] UKHL 12, [2004] 1 WLR 807. See also the European cases McKerr v UK (2002) 34 EHRR 20; Kelly v UK [2001] Inquest LR 125.

74 See eg Leonard Hoffmann, 'The Universality of Human Rights' (2009) 125 Law Quarterly Review 416.

$75 R$ (Amin) v Secretary of State for the Home Department [2003] UKHL 51, [2004] 1 AC 653.

76 Harlow (n 66) 26; Law Commission, Administrative Redress: Public Bodies and the Citizen (Consultation Paper 187, 2008) 148 .

77 See eg McBride and Bagshaw (n 13) 30 - 33,199.

78 Cf Broome v Cassell E Co Ltd [1972] AC 1027, 1114.

79 Cf Adrian AS Zuckerman, Civil Procedure (LexisNexis, 2003) $\$$ 10.66 - 10.67; JA Jolowicz, ‘Civil Litigation: What is it For?' (2008) 67 Cambridge Law Journal 508, 512 - 13; and, more generally, JA Jolowicz, On Civil Procedure (Cambridge University Press, 2000) 396. 
80 See eg Adam Tomkins, Our Republican Constitution (Hart Publishing, 2005) 67 - 87, passim; JAG Griffith, 'ThePoliticalConstitution' (1979)42Modern Law Review 1.

81 This was pointed out some time ago. See Richard Crossman, Introduction to Walter Bagehot, The English Constitution (Fontana, 1993 [1963]) 1, 43 - 47.

$82 R v$ Secretary of State for the Home Department, ex parte Fire Brigades Union [1995] 2 AC 513, 567; to the same effectseeLordWoolf, 'DroitPublic-EnglishStyle' [1995]PublicLaw57,58.

83 See Robert Stevens, The English Judges: Their Role in the Changing Constitution (Hart Publishing, revised edn 2005) 75 .

$84 R$ (Gillan and another) $v$ Commissioner of Police of the Metropolis [2006] UKHL 12, [2006] 2 AC 307; Van Colle v Chief Constable of the Hertfordshire Police [2008] UKHL 50, [2009] 1 AC 225.

85 Sarah Lyall, 'Britain' s Antiterror Officer Resigns' New York Times, 9 April 2009; see also Suzanne Bosman, 'Police in Danger of Losing Public Trust' The Guardian, 9 April 2009; David Howarth, 'The Police Misled Us' The Guardian, 8 April 2009; Leader, 'Answers Please’ The Times, 9 April 2009.

86 English tort law may be indirectly responsible for another source of insufficient oversight of the police: an overbroad defamation law made newspapers apprehensive about publishing stories alleging excessive use of force by the police. See Eric Barendt et al, Libel and the Media: The Chilling Effect (Clarendon, 1997) 188. Changes in the law subsequent to the publication of this book may have altered that. 